\title{
A qualitative study on the administration and management competencies in a Brazilian dental school
}

Aline Cláudia Ribeiro Medeiros*; Mitsue Fujimaki**; Dayla Thyeme Higashi***; Maria Celeste Morita****; Talissa Mayer Garrido*; Raquel Sano Suga Terada**

* DDS, Department of Dentistry, State University of Maringá, Paraná, Brazil

** Associate Professor, Department of Dentistry, State University of Maringá Paraná, Brazil

*** PhD Student, Department of Dentistry, State University of Maringá, Paraná, Brazil

Associate Professor, Department of Oral Medicine, State University of Londrina, Paraná, Brazil

\begin{abstract}
This qualitative study evaluated the acquisition of administration and management (A\&M) competencies during graduation in a Brazilian dental school. Interviews were held with 13 dentists, whose opinions were examined with thematic content analysis. The perception about the acquisition of the competencies necessary to perform their jobs occurred when they were in the daily practice after graduation. Respondents reported being insufficiently trained, resulting in a series of difficulties to manage their daily professional activities after leaving dental school, particularly regarding financial issues. Different strategies are required and more effort needs to be placed on the development of A\&M competencies to better prepare recently graduated dentists to enter the work market.
\end{abstract}

Descriptors: Education, Dental. Professional Competence. Disease Management. Practice Management, Dental. Health Services Administration.

\section{INTRODUCTION}

Brazil outstrips the whole of Europe and the United States in the number of dental schools $^{1}$. At present, there are around 269.290 dental professionals registered with the Brazilian Federal Dental Council, and an average of 9,000 new dentists graduate each year $^{2}$. This scenario has led to important concerns, both in regard to the quality of the education offered and the adequacy of dental professionals joining the work market ${ }^{1}$.

Dental care involves several competencies and skills, at both clinical and non-clinical levels, required in public and private practices. When joining the work market, the young professional always faced with several administrative and managerial tasks, such as the acquisition of dental materials, purchase and maintenance of equipment, keeping accountancy records, the supervision of other professionals, leadership, and the general organization of their activities 
based on patient needs and resources available. Although not necessarily perceived by the patient, each of these tasks can directly affect the care provided, and can be of fundamental importance to establish a differential in an increasingly competitive market. As a result, the application of modern administration and management (A\&M) concepts has become essential to achieve professional success ${ }^{3}$. Nonetheless, although dental schools aim to form competent professionals who are properly prepared for the work market, a gap in the development of professional A\&M competencies is perceived.

For a long time, dental education has primarily focused on the biological sciences and the clinical knowledge and skills considered essential for the practice of the profession ${ }^{4}$. At the end of the $20^{\text {th }}$ century, curricular changes were proposed for dental schools in Brazil and in the world ${ }^{5}$. One of the main alterations suggested concerns the reorientation of pedagogical practices directed towards the construction of several different competencies. The justification for these changes were based on the need to suit professional education to the present demands of society ${ }^{6,7}$.

With the National Curricular Guidelines (NCG) for dental courses launched by the Brazilian Ministry of Education in 2002, a new professional profile for dentists was proposed based on the development and evaluation of competencies acquired by undergraduates. Taking into consideration the transformations that have been taking place in the working market, general competencies indispensable for the adequate exercise of the dental profession, such as A\&M, were defined through these guidelines ${ }^{8}$. In accordance with the provisions set in the NCG, which entail an education focused on the country's national health system, professionals are supposed to be capable of taking initiatives and conducting A\&M tasks involving all the necessary human, physical and material resources and information technology required for the adequate running of dental offices both at private and public levels ${ }^{8}$. Within this context, it is now required that students are educated in A\&M processes that can be applied to different social, cultural and geographical groups.

Nonetheless, despite the effort to better qualify dental professionals in their A\&M skills, the general perception is that the result has been less than ideal, with the majority of students/professionals seeming to feel unprepared to manage their professional careers immediately after concluding dental school $^{9-11}$. Hence, interventions may be necessary to bridge the existing gap between training and management practices in the daily events of the dental profession. However, in a continuous process to implement improvements in the dental curricula, it is important to give voice to recently graduated dentists to better understand $\mathrm{A} \& \mathrm{M}$ competencies required to private practice, developed during graduation course.

Therefore, the aim of this qualitative study was to collect and analyze personal points of view of dentists recently graduated from a public dental school in the city of Maringá (Brazil) on their acquisition of professional A\&M competencies during graduation, and the effect they had on their private practice.

\section{METHODOS}

This is a qualitative study, descriptive and exploratory in nature, performed according to the recommendations established in the consolidated criteria for reporting qualitative research (COREQ $)^{12}$. This 
research was initiated after the appreciation and approval from the Ethics Committee on Research Involving Human Beings of the State University of Maringá (CAAE No. 0475.0.093.000-10). All subjects signed a term of free and informed consent before participating in the interviews.

In order to provide rich, relevant and diverse data pertinent to the research question, a purposive sample with participants who shared the same characteristics was used. The sample was composed by dental graduates, who had completed their course in 2009 from the same public dental school in the municipality of Maringá, Brazil. All the participants were living and working in Maringá, and had been practicing for at least one year in private practice. Participants were personally contacted through emails, when they were fully informed on the purposes of the interviews and invited to participate in the study. After acceptance, date and time for the interviews were scheduled. All data were collected by just one interviewer (ACRM).

To avoid any type of external factor that might have led to any reservations on the participating subjects' part, interviews were carried out in an office located at the dentistry department, at a time of their convenience. No one apart from the researcher and the participant were present during the interviews.

The interviews were based on a semistructured script, in which participants were asked about the contribution made by the dental school curriculum in the construction of A\&M competencies during their dental training and practicing.

Participants were encouraged to talk with the use of open-ended questions. Rewording, re-ordering or clarifying the questions were employed in an attempt to explore in-depth their personal points of view on the theme. Data were collected with the use of a voice-recorder (SONY ICD- PX820) and Camtasia Studio Software program (Okemos, MI, United States). Interviews were not repeated and participants were consecutively recruited until no new relevant knowledge was obtained from new participants (data saturation).

Participants' recorded statements were manually transcribed to permit longitudinal reading. The transcribed text was then edited without, however, being altered. Transcriptions were returned to the participants who had the opportunity to check them for accuracy and make their comments. No changes were made to the transcriptions. For data analysis, Bardin's thematic content analysis was adopted ${ }^{13}$. The data collected were treated in the following stages: preanalysis, exhaustive exploration of the material, data co-treatment and interpretation. Once the interviews were recorded and transcribed, statements were selected and classified into thematic categories associated with the perception of each participant. Each subject was identified with a number (R1R13) according to the order they were interviewed.

\section{RESULTS}

A total of 13 respondents aged between 24 and 30 years, 11 female and 2 male, participated in the study.

The results of the analyses of the semistructured interviews are presented under thematic headings. These headings demonstrated to be directly associated to the effect the dental curriculum had on the acquisition of A\&M competencies: 1) Development of A\&M competencies during graduation; 2) Difficulties concerning A\&M competencies in the exercise of the profession; and 3) Construction of A\&M competencies in professional practice. 
A qualitative study on the administration and management competencies in a Brazilian dental school

\section{Development of $A \& M$ competencies during graduation}

Based on the results obtained from the analyses of the interviews, it was observed that all respondents, without exception, reported that A\&M competencies were insufficiently dealt with during their graduation course. In their opinion, the development of A\&M competencies was deficient, fragmented, addressed in a very rapid, superficial manner, hardly affecting their training:

R2: " [...] administration and management, as I have said, I think it leaves a lot to be desired."

R6: "Administration and management was worked on very little, extremely little. The student only learns to administer his/her time, which is frequently poorly administered."

Two respondents stated that the failure in developing A\&M competencies occurs in undergraduate courses in general, and is not a limitation specifically seen in their graduation course:

R10: "Certainly not. I think this is the same at any college, I think everyone has this difficulty."

R1: "I think it is faulty, administration and management, not only here, isn't it? As far I can see, I think dental courses in general fail, not only here [...]"

One respondent expressed the idea that the failure in developing A\&M competencies may be the result of teachers being inadequately prepared:

R5: "[...] the administration and management part was one of the parts that were rather deficient in our graduation, and I don't know if it is only in our graduation. However, I think it has been deficient in the large majority of dental courses. I don't know if it is because they don't give this job to a really competent person, for example, an accountant, an administrator, and it ends up being the dentistry teachers themselves who teach this subject, but anyway, it is a limitation in the majority of courses I know."

One respondent stated that apart from the fact that A\&M competencies were insufficiently worked, the students, in general, did not appreciate the activities carried out in class either:

R13: "This, I think, it was the little time that we had [...] when one were going to have a lesson in this [administration and management] at college, one didn't appreciate it at all [...]"

\section{Difficulties found in exercising the profession}

Respondents reported that when they were faced with the reality of managing a dental office they were met with several difficulties. They had no idea how to form the price to be charged for a dental treatment, were unaware of all the taxes to be paid, or how to deal with assistants and suppliers. The following is what they stated concerning the training they received in college:

R4: "[...] to have this notion as soon as you leave college, not really, I had much difficulty in administering the dental office."

R6: "[...] the question of management and administration of your clinic when you leave college, your money, when you work for someone, that was a problem [...]"

R8: "[...] you do not leave college with a great deal of preparation, knowing how to administer a dental office."

R10: "[...] I did not know how to manage, I was afraid to open a dental office because of the question of rates and taxes, and that was all very complicated."

R13: "In my case, I did not suffer a great deal with this, because he (her husband) already had a dental office open; however, when he opened his 
A qualitative study on the administration and management competencies in a Brazilian dental school

dental office he had no idea of what to do, everything he had to pay [...] we have to pay a lot of things every month, a lot of taxes that we had never imagined."

\section{Construction of the competence in professional practice}

For the participants, A\&M competencies were most effectively constructed in the professional practice, in the day-to-day running of the dental office affairs and the clinical routine.

R11: "[...] we learn in the practice." R8: "[...] this (A\&M), one only learns in the work market, isn't it? [...] one goes on learning more in, in their day-to-day clinical routine, isn't it?"

\section{DISCUSSION}

The qualitative approach chosen for this exploratory study aimed at collecting participants' perceptions and feelings in order to go deeper into the meaningful world of human actions and relationships, a side that is not perceptible and cannot be captured by quantitative methods. The need to provide students with A\&M competencies is deemed to be essential not only for the exercise of the profession in the private sector, but also to meet management demands in the public health system.

In line with the proposals established by the NCG, the dental course curriculum in question has been based on a pedagogic model denominated Integrated Multidisciplinary Curriculum (IMC). The IMC's main goal is to provide dental students with generalist education through the integration of several different health areas. In the present institution, to implement the development of A\&M competencies a new subject matter denominated Professional Guidance was devised, to be taught in the second and fourth year. Among the objectives of this new subject are the acquisition of organizational, planning, and administration skills as well as the evaluation of dental services. Students receive guidance on management and marketing $(34 \mathrm{~h})$, legal aspects involving dentistry (17 h), information technology (22 h), ergonomics $(17 \mathrm{~h})$, bioethics $(8 \mathrm{~h})$ and patient/clinician relationships (12 h).

Although these subjects have been specifically designed for the development of A\&M competencies, they do not seem to be sufficient to provide the necessary autonomy to the future dental professional, particularly taking into consideration the amplitude and depth of knowledge required to face the contemporary work market ${ }^{5}$. This is a reality observed not only in the dental course in question, but also in other dental graduation courses in both this country and abroad ${ }^{3,4,14,15}$.

The limitations of the curricular model adopted became evident in the answers provided by those who were trained under this structure. Respondents did not feel the efforts to address $\mathrm{A} \& \mathrm{M}$ competencies required to private practice during graduation had an important effect on their professional life. Among the various difficulties reported after leaving college regarding A\&M practices, respondents felt unprepared to run the daily affairs of a dental office, particularly concerning price formation for dental treatments and the payment of taxes and expenses. Respondents indicated that the knowledge they possessed in A\&M practices was the result of their professional experience acquired after the conclusion of the graduation course. One possible explanation for this perception is that all the respondents in the present study had either started their own practices, or were working for others in the private sector, situations in which A\&M skills were acquired under the mentorship/guidance 
A qualitative study on the administration and management competencies in a Brazilian dental school

of a senior dentist. Nonetheless, the situation of those who venture in the public sector does not seem to be different. Bernabe et. al. $(2006)^{16}$ reported that recently graduated dentists considered themselves to have been insufficiently trained during their formal education for the various functions related to the practice of management in public dental care.

Respondents suggested that interest for classes and events on management was poor with most students not taking advantage of the opportunities provided by teachers. Possibly, some students did not see the relevance of their education in management practice during their years at college because they are focused on acquiring the necessary technical skills to practice the profession ${ }^{17}$. Even though some aspects of management practice are provided by the institution during their clinical education, only when they enter the work market they begin to understand that there are other areas of their practice that also require development ${ }^{3}$. Part of the poor interest in $\mathrm{A} \& \mathrm{M}$ contents in the dental course was attributed to the fact that teachers were dentists rather than accountants or administrators. While it is true these professionals may be more qualified to deal to administration and financial issues, the teachers in question are successful dentists who could be seen as a model of excellence in the profession ${ }^{18}$. Therefore, the lack of interest may lie more on the structure of the course itself, rather than on the qualifications teachers have.

Further important aspect is that the graduation stages are all done in public health system, thus the private clinic practice is not applied, leaving gaps as material purchasing, procedure value and resource management. The content about private clinic is ministered only in theoretical classes, which is insufficient for learning.

Morita et al. $(2010)^{8}$ reported some topics regarding A\&M competencies, based in the NCGs, that can be used to structure and measure these skills in curricula. At first competencies related to management of human and financial resources, as well as marketing and strategic planning should be applied and be integrated with all the subjects throughout all years of study, on this way taking part of the clinical routine, administration and management will naturally take part of the student's craft. At second, encourage clinical stages, both in public and private sectors, providing to the academic a large practice settings experience. At least the personal management needs to be stimulated, improving the individual concepts and practices related to interdisciplinary and multidisciplinary skills, solving problems that occurs in the faculty and promoting leadership actions.

Analysis and evaluation of the curricular model must constantly occur in order to verify whether proposed changes are having the desired impact on the formation of the professional profile based on the competencies necessary for the proper practice of dental care. The results of this study highlight the necessity to review the time dedicated, and the manner that A\&M competencies are being delivered and evaluated. The present model needs adjustment to adequately train graduate students for the private work market. An integrated curriculum involving human and financial resources management, data management, marketing and strategic planning should be incorporated across all subjects in the curriculum right from the beginning and along the entire course, including private and public practices. The introduction of routine observations in private 
and public dental offices of different sizes during supervised training would also provide students with the hands on experience they require concerning A\&M skills. Finally, right from start, the course should work on the concepts and practices of human relations and the humanization of dental care, encouraging interdisciplinary and multi-professional work. More studies are necessary to better understand and identify deficiencies before propose changes in the pedagogical project of the course.

\section{CONCLUSIONS}

The results found in this study demonstrated that different strategies are required and more effort needs to be placed on the development of A\&M competencies to better prepare recently graduated dentists to enter the work market. Based on the statements collected from respondents, more time dedicated to A\&M training during graduation with adequate practices are needed. As consequence, after concluding the course, respondents stated having several difficulties when entering the work market, particularly when dealing with financial affairs. Moreover, from the participants' point of view, A\&M competencies were only more effectively developed in a practical manner after graduation, in the practice of the profession.

\section{RESUMO}

Estudo qualitativo sobre as competências de administração e gestão de carreira em uma escola de Odontologia Brasileira

Este estudo qualitativo avaliou a aquisição de competências de administração e gerenciamento $(A \& G)$ durante a graduação em uma escola de Odontologia brasileira. Foram entrevistados 13 dentistas e as suas opiniões foram analisadas por meio de análise de conteúdo temática. A aquisição de competências necessárias para o exercício profissional ocorreu somente após a graduação. Os entrevistados relataram que não foram suficientemente treinados, em relação a administração e gerenciamento de suas carreiras, o que resultou em uma série de dificuldades em lidar com a prática profissional. Para desenvolver as competências de A\&G e melhor preparar o profissional para o mercado de trabalho são necessários novos esforços e diferentes estratégias de ensino/aprendizagem.

Descritores: Educação em Odontologia. Competência Profissional. Gerenciamento Clínico. Administração da Prática Odontológica. Administração de Serviços de Saúde.

\section{REFERENCES}

1. Saliba NA, Moimaz SA, Garbin CA, Diniz DG. Dentistry in Brazil: its history and current trends. J Dent Educ. 2009;73(2):225-31.

2. (CFO) Conselho Federal de Odontologia. Dados estatísticos. 2016. Available at: http://cfo.org.br/servicos-e-consultas/Da dos-estatisticos/?elemento=profissionais \&categoria $=\mathrm{CD} \& \mathrm{cro}=$ Todos\&municipio

3. Barber $\mathrm{M}$, Wiesen $\mathrm{R}$, Arnold $\mathrm{S}$, Taichman RS, Taichman LS. Perceptions of business skill development by graduates of the University of Michigan Dental School. J Dent Educ. 2011;75(4):505-17.

4. Comer RW, Callan RS, Blalock JS, Turner JE, Trombly RM. Small business needs assessment: a comparison of dental educators' responses with SBDC survey results. J Dent Educ. 2001;65(9):866-73.

5. Zilbovicius C, de Araujo ME, Botazzo C, Frias AC, Junqueira SR, Junqueira CR. A paradigm shift in predoctoral dental curricula in Brazil: evaluating the process of change. J Dent Educ. 2011;75(4):55764.

6. Wesselink RB, Biemans HJA, Mulder M, 
van den Elsen, ER. Competence-based VET as seen by Dutch researchers. EJVT. 2007; 40(1): 38-51.

7. Frenk J, Chen L, Bhutta ZA, Cohen J, Crisp N, Evans T, et al. Health professionals for a new century: transforming education to strengthen health systems in an interdependent world. Lancet. 2010;376(9756):1923-58.

8. Morita $\mathrm{MCH}$, Haddad AE, De Araújo ME. Perfil atual e tendências do cirurgião-dentista brasileiro. Dental Press. 2010.

9. Ralph WJ, Stewart BL, Macmillan $\mathrm{CH}$. Survey of dental practice/dental education in Victoria. Part II. Recent graduates/graduating students. Aust Dent J. 1990;35(1):69-75.

10. Valachovic RW, Weaver RG, Haden NK, Robertson PB. A profile of dental school deans. J Dent Educ. 2000;64(6):433-9.

11. Bertolami CN. Creating the dental school faculty of the future: a guide for the perplexed. J Dent Educ. 2007;71 (10):1267-80.

12. Tong A, Sainsbury P, Craig J Consolidated criteria for reporting qualitative research (COREQ): a 32-item checklist for interviews and focus groups. International journal for quality in health care. Int J Qual Health Care. 2007;19(6):349-57.

13. BARDIN L. Conten Analysis. Lisbon. 2004;70.
14. Henzi D, Davis E, Jasinevicius R, Hendricson W. In the students' own words: what are the strengths and weaknesses of the dental school curriculum? J Dent Educ. 2007;71 (5):632-45.

15. Houlberg BJ. Dental residents' perceptions of practice and patient management training during postgraduate education. J Dent Educ. 2008;72(6):64352.

16. Bernabe E, Ludena MA, Beltran-Neira RJ. Self-perceived public health competency among recent dental graduates. J Dent Educ. 2006;70(5):5719.

17. Pickworth GE, Snyman WD, White JG, Beukes SJ. The dilemma of student attendance of learning opportunities. SADJ. 2005;60(2):73-7.

18. Willis DO. Using competencies to improve dental practice management education. J Dent Educ. 2009;73 (10):1144-52.

Correspondência para:

Raquel Sano Suga Terada e-mail:rssterada@uem.br Department of Dentistry, State University of Maringá

Av. Mandacaru, 1550

87080-000 Maringá, Paraná, Brazil 